\title{
INFLUENCE OF GOVERNMENTAL SUBSIDIES ON GROWTH OF PHOTOVOLTAIC ENTERPRISES: EMPIRICAL EVIDENCE FROM CHINA
}

\author{
Ya'ou ZHANG \\ College of Aeronautics Zhongyuan- Petersburg, Zhongyuan University \\ of Technology, Zheng Zhou, 450007 China; \\ E-mail:19088882@qq.com
}

\begin{abstract}
As an emerging industry, photovoltaic industry has won strong support from the government. However, many problems appear in industrial development with increasing maturation of photovoltaic industrial development. The governmental effect has a critical bearing on photovoltaic industrial development as governmental policies-driven industry. In order to investigate the influence of governmental intervention on growth of photovoltaic enterprises, sample data related to photovoltaic enterprises in Chinese A-share market during 2007-2017 were selected, and the influences of fiscal subsidies and tax preferences on growth of photovoltaic enterprises were analyzed. The results show that both fiscal subsidies and tax preferences have positive promoting effects on growth of photovoltaic enterprises and influence of fiscal subsidies is more obvious. The conclusions provide decision-making support for the government to formulate intervening policies facilitating growth of photovoltaic enterprises.
\end{abstract}

Keywords: governmental subsidies, growth, photovoltaic enterprises

\section{INTRODUCTION}

With rapid economic development in China, excessive resource consumption and environmental damage caused by extensive-type economic development have become problems needing urgent solutions. In order to promote sustainable socio-eco- nomic development, facilitate comprehensive upgrading of industrial structure and relieve enormous pressure brought by resource environment, transforming economic development mode is a feasible measure. As a renewable energy source, solar energy has numerous advantages like cleanness, no pollution, no regional limitations, inexhaustible property, etc. Photovoltaic industry is enterprise set, which converts solar energy into electric energy through photovoltaic effect to form industrial chain of photovoltaic conversion, including production of polycrystalline silicon raw material, production of solar batteries and components, manufacturing and application of related equipment, etc. [1]. Therefore, photovoltaic industry is of environmental friendly feature and has drawn much concern of national governments.

Governments the world over have formulated numerous subsidy policies for industrial development to promote development of photovoltaic industry. Germany is the first country, which implements industrial policies to support photovoltaic industry and enacted feed-in tariff subsidy policies. The United States tends to tax incentive and preferential policies [2], and China has implemented "golden roof program", "top runner program” and all kinds of subsidy and incentive policies in order to support development of photovoltaic industry. Governmental subsidy support exerts important promoting effect on rapid development of Chinese photovoltaic industry [3]. Firstly, governmental subsidy policies facilitate continuous expansion of industrial scale. 
Polycrystalline silicon output reached $194,000 \mathrm{t}$ in 2016 with $17.5 \%$ year-on-year growth rate. Silicon wafer output was about $63 \mathrm{GW}$ with $31.2 \%$ year-on-year growth rate. Output of photovoltaic modules was about $53 \mathrm{GW}$ with $20.7 \%$ year-onyear growth rate. Added installed capacity in photovoltaic grid connection reached $34.5 \mathrm{GW}$ with $127 \%$ year-on-year growth rate. Proportions of production scales in various links of photovoltaic industrial chain all exceeded $50 \%$ in the globe, ranking the first place. Secondly, governmental subsidy policies promote good prospect of operation state of photovoltaic enterprises. In 2016, number of enterprises occupied in photovoltaic industrial production reached over 2,000, and average profit rate of enterprises increased by 3 percentages in China. Among listed photovoltaic enterprises, 9 ones enjoyed profit growth with amplitudes exceeding $100 \%$. Finally governmental subsidy policies accelerate industrialization of advanced technologies. Industrialization of a batch of high-efficient crystalline silicon photovoltaic cell technologies, like black silicon texturizing, back face passivation (PERC), and $n$-type double face, is accelerated. Average conversion efficiency of monocrystal and polycrystalline batteries has reached $20.5 \%$ and $19.1 \%$; polycrystalline silicon production technology has been further optimized.

It can be seen that rapid development of Chinese photovoltaic industry is closely related to growth of photovoltaic enterprises. Favourable growth of photovoltaic enterprises can promote benign development of photovoltaic industry. As governmentally supported industry, rapid development of photovoltaic industry can't go without governmental policies. Governmental subsidy is a common means of the governmental supporting development of photovoltaic industry. In order to facilitate smooth and benign development of photovoltaic industry, analyzing influence of governmental policies on growth of photovoltaic enterprises helps to figure out action mechanism of governmental intervention on photovoltaic industry and provides theoretical reference and decision-making support for formulation of governmental policies.

\section{THEORETICAL ANALYSIS AND HYPOTHESES}

As an important constituent part of industrial policies and fiscal policies, governmental subsi- dy can boost economic structural adjustment. Fiscal taxation policy refers to the fact that on the one hand, a country allocates fiscal resources, perfect scientific and technological public infrastructure, increase input of R\&D innovation expense and reach the goal of reducing technological innovation risks of enterprises according to enterprise demands for public finance. On the other hand, it reduces enterprise production cost through tax preferences. Policies motivating enterprises to conduct R\&D innovation and governmental fiscal taxation policies implemented for enterprises can release partial governmental earnings to enterprises to realize governmental goal of supporting one industry so as to reduce enterprise production cost and operation risk, increase profit and finally promote enterprise development. The fiscal and taxation policy guides the role of social resources to the industries that the government wants to support, so as to enhance the innovation and competitiveness of enterprises. F. Bergström [4] found that government subsidies increased the economic value added of enterprises and promoted the growth of enterprises. Research conducted by K. Dongmin et al. [5] found that governmental subsidies improved enterprise operating performance and social responsibility and for state-owned enterprises governmental subsidies had more obvious improving effects on operating performance and social responsibility of private enterprises. A. Cerqua \& G. Pellegrini [6] analyzed Italian fiscal subsidy policies and found that fiscal subsidies significantly enlarged employee scale of the enterprise receiving the subsidy, investment level and company growth.

The fiscal taxation policy support for photovoltaic enterprises can not only solve problems like financial difficulty encountered during enterprise development process and compensate for deficiencies of market economy but also can facilitate enterprises to improve their own R\&D innovation abilities so, as to boost growth of photovoltaic enterprises. As an emerging industry, photovoltaic industry needs enormous capital input during development process due to high technical requirements, but unavoidable contradictions still exist during development process of photovoltaic industry because of problems existing in financing mechanism and governmental supportive policy mechanism mainly including national fiscal taxation policy guidance and insufficient innovative impetus of the enterprises themselves. It's generally believed in theoretical ex- 
ploration that the government should give full play to supportive effect of governmental fiscal subsi$\mathrm{dy}$ and enhance incentive and guiding effect of preferential tax policies. The government can facilitate photovoltaic enterprises to actively innovate and boost rapid and stable development of photovoltaic industry through coordination and cooperation of the two. Governmental fiscal subsidy and tax preference belong to the main part of fiscal taxation policy, so the government actively exerting effects of fiscal subsidies and tax preferences on photovoltaic industry is of critical importance to industrial development. According to the above analysis, fiscal subsidies and tax preferences can solve problems of photovoltaic enterprises like financial difficulty and insufficient innovation ability so as to promote growth of photovoltaic enterprises, based on which the following hypotheses are proposed:

Hypothesis 1: Fiscal subsidies have positive effect on growth of photovoltaic enterprises.

Hypothesis 2: Taxation preference has positive effect on growth of photovoltaic enterprises.

In addition, compared with fiscal subsidies, tax preference has some apparent defects: firstly, in terms of action objects, most preferential tax policies implemented in China are only effective for profitable enterprises in the same year, but for unprofitable enterprises and newly built enterprises without operation revenue yet, they can't enjoy these preferential policies in reality. However, for large enterprises in mature stage, these newly built enterprises and medium and small-sized enterprises have more intense demands for R\&D support [7]; secondly, from the time when the policies take effect, tax preference exerts effect slower, and influence of fiscal subsidies is more direct and rapidly; thirdly, as for cost, implementation cost of preferential tax policies (like administrative cost of relevant departments, declaration cost of taxpayers, etc.) is higher than that of fiscal subsidies [8]. Based on the above analysis, the following hypothesis is proposed:

H3: Compared with tax preferences, fiscal subsidy can more obviously improve growth of photovoltaic enterprises.

\section{METHODOLOGY}

101 listed photovoltaic companies were searched from Pole Star Solar Photovoltaic Website (http://guangfu.bjx.com.cn/), 33 companies lis- ted abroad like in New York and 13 companies listed after 2007 were excluded, 55 photovoltaic enterprises listed in Shenzhen Stock Exchange and Shanghai Stock Exchange were obtained, and finally data of the 55 listed photovoltaic enterprises during 2007-2017 were selected as research samples. All data used in this study were from annual reports announced by listed companies (source: Shenzhen Stock Exchange Website, Shanghai Stock Exchange Website and Cninf Website) and CSMAR database, and SPSS22.0 software was used during empirical analysis process to complete the models as follow:

$$
\begin{aligned}
& G_{t+1}=a_{0}+a_{1} F_{t}+a_{2} C_{t}+e, \\
& G_{t+1}=b_{0}+b_{1} T_{t}+b_{2} C_{t}+e,
\end{aligned}
$$

where $G$ is explained variable representing enterprise growth. According to finds of R.M. Stulz on enterprise growth evaluation [9], Tobin's $Q$ value is selected in this study to measure growth of photovoltaic enterprises. Explaining variables $F$ and $T$ express fiscal subsidy and tax preference respectively. Direct fiscal subsidy and tax refund are the most common means of governmental subsidies [10], so fiscal subsidy and tax preference are selected in this paper as explaining variables to study their influences on enterprise growth. Variables in the model were fiscal subsidy and tax preference, relative indexes, which were obtained by dividing enterprise total asset by direct subsidy amount and dividing enterprise total asset by tax preference, were respectively selected, and lag one variables were selected combining lag features of governmental subsidies. $C$ was combination of control variables, and photovoltaic enterprise scale, financial leverage, technological innovation ability, equity concentration, and capital structure were selected as control variables. Concrete variable settings are shown in Table 1.

\section{RESULTS ANALYSIS AND DISCUSSION}

\subsection{Descriptive Statistical Analysis}

Table 2 lists descriptive statistical results of explained variables, explaining variables and control variables.

As shown in Table 2, mean value of comprehensive growth scores of photovoltaic enterprises 
Table 1. Descriptions of Main Variables

\begin{tabular}{|l|l|c|l|}
\hline \multicolumn{1}{|c|}{ Variable type } & \multicolumn{1}{|c|}{ Variable } & Symbol & \multicolumn{1}{c|}{ Variable explanation } \\
\hline Explained variable & Growth & $G$ & Tobin's Q \\
\hline \multirow{5}{*}{$\begin{array}{l}\text { Explaining } \\
\text { variable }\end{array}$} & Fiscal subsidy & $F$ & Direct subsidy amount/total asset \\
\cline { 2 - 5 } & Tax preference & $T$ & Tax preference amount/total asset \\
\hline \multirow{5}{*}{ Control variable } & Enterprise scale & Size & Logarithm of enterprise total asset \\
\cline { 2 - 5 } & Financial leverage & DEL & $\begin{array}{l}\text { (Net profit + income tax expense + financial expense)/ } \\
\text { (net profit + income tax expense) }\end{array}$ \\
\cline { 2 - 5 } & $\begin{array}{l}\text { Annual dummy } \\
\text { variable }\end{array}$ & Year & $\begin{array}{l}\text { It's taken as 0 when it's in the same year, or otherwise } \\
\text { it's taken as 1 }\end{array}$ \\
\cline { 2 - 5 } & Equity concentration & CON & $\begin{array}{l}\text { Shareholding ratio of the first majority shareholder=- } \\
\text { total shares held by the first majority shareholder/total } \\
\text { number of shares }\end{array}$ \\
\cline { 2 - 5 } & Capital structure & Debt & Debt/asset ratio \\
\cline { 2 - 5 } & $\begin{array}{l}\text { Technological innova- } \\
\text { tion ability }\end{array}$ & $R D I$ & R\&D expenditure/main business income \\
\hline
\end{tabular}

Note: Both amounts of explaining variables governmental subsidy and tax preference and amount of R \& D expenditure calculating technological innovation ability in control variables come from annual reports of listed companies and are obtained by the author through artificial collection; other data come from CSMAR database.

is 0.0001 , maximum value is 1.76 , minimum value is -2.74 , difference between maximum value and minimum value is 4.5 and standard deviation is 0.46617 , indicating that growth difference between sample companies is not great. Maximum value of governmental subsidy is 89.56 , minimum value is 0 , difference between maximum value and minimum value is 89.56 and standard deviation is 7.61276 , indicating that great difference exists in governmental subsidies obtained by sample companies, possibly because some sample enterprises have not obtained national fiscal subsidies in some years within the research interval. Maximum value of tax preference is 10.14 , minimum value is 0 , difference between maximum value and minimum value is 10.14 and standard deviation is 1.09457 , indicating great difference in tax preferences given to sample companies, possibly because many enterprises have not obtained preferential tax policies actually or tax preferences have not been given to listed photovoltaic enterprises in some years within sample research interval.

\subsection{Analysis of Regression Results}

Table 3 presents results of multivariate regression analysis.
From regression results in model (1), regression coefficient of fiscal subsidy $(F)$ is 0.056 and passes $T$ hypothesis testing at $5 \%$ significance level [11], indicating that influence of fiscal subsidies on growth of photovoltaic enterprises is positive. According to regression results of mode (2), regression coefficient of tax preference $(T)$ is 0.003 and passes $T$ hypothesis testing at $10 \%$ significance level, indicating that tax preference has positive influence on growth of photovoltaic enterprises. The greater the fiscal input, the better the growth of photovoltaic enterprises. The stronger the tax preference, the better the growth of photovoltaic enterprises, and the two verify hypotheses 1 and 2, and this is consistent with research findings of $\mathrm{L}$. Xuhong, B. Charles \& M. Pierre, and L. Chuanxian \& L. Xiaoyu [12-14]. In addition, in terms of regression coefficients of fiscal subsidy $(F)$ and tax preference $(T)$, fiscal subsidy $(F)$ coefficient 0.056 is greater than tax preference $(T)$ coefficient 0.003 , indicating that compared with tax preference, fiscal subsidy has greater influence on growth of photovoltaic enterprises, so hypothesis 3 is verified.

It can be seen from empirical results that during the process of supporting development of photovoltaic industry, the government should manage the relationship between governmental effect and 
Table 2. Descriptive Statistical Results of Variables

\begin{tabular}{|l|c|c|c|c|c|}
\hline \multicolumn{1}{|c|}{ Variable } & Symbol & $\begin{array}{c}\text { Maximum } \\
\text { value }\end{array}$ & $\begin{array}{c}\text { Minimum } \\
\text { value }\end{array}$ & Mean value & $\begin{array}{c}\text { Standard } \\
\text { deviation }\end{array}$ \\
\hline Growth & $G$ & 1.76 & -2.74 & 0.0001 & 0.46617 \\
\hline Fiscal subsidy & $F$ & 89.56 & 0.00 & 4.8109 & 7.61276 \\
\hline Tax preference & $T$ & 10.14 & 0.00 & 0.3989 & 1.09457 \\
\hline Enterprise scale & Size & 11.39 & 8.67 & 9.5924 & 0.50109 \\
\hline Financial leverage & $D E L$ & 13.59 & -13.07 & 1.6525 & 1.73527 \\
\hline Annual dummy variable & CON & 0.71 & 0.000 & 0.3481 & 0.14040 \\
\hline Equity concentration & Debt & 1.20 & 0.06 & 0.5311 & 0.17301 \\
\hline Capital structure & $R D I$ & 0.28 & 0.00 & 0.0157 & 0.02795 \\
\hline
\end{tabular}

market, respect market laws, select proper intervention mode and degree, give full play to supporting effect of governmental fiscal subsidies and incentive and guiding function of preferential tax policies and encourage photovoltaic enterprises to conduct self-innovation so as to promote their own development. The government should enlarge capital input, support development of medium and small-sized photovoltaic enterprises and perfect pathways like capital market to promote development of photovoltaic industry from the angle of fiscal subsidy. But it should further perfect fiscal subsidy mechanism, using sufficient capital to support related enterprises, which play leading roles in science and technology, while for photovoltaic enterprises with bad development prospect or those that are disqualified, the government should respect "survival of the fittest" market rule to reduce unnecessary waste of capital. Secondly, superior resources should be integrated. R\&D tasks of key technologies should be carried out by building national-level photovoltaic technological development institutes and combining development status and concrete conditions of photovoltaic industry, like studying new-type solar cells [15]. Thirdly, special funds for development of photovoltaic industry should be set up to promote innovative $R \& D$ activities of photovoltaic enterprises.

From an angle of taxation, the government should stimulate innovation of photovoltaic enterprises to give full play to governmental intervention effect by means of intensifying tax preferences, formulating specialized preferential tax reduction and exemption policies and reducing cost of tax payment. Firstly, partial technological R\&D expense can be used to offset certain tax to reach the goal of improving innovation ability while reducing enterprise production and operation cost, and risk allowance for R\&D can be withdrawn according to certain proportion of operation revenue of photovoltaic enterprises and is allowed to be deducted before taxation by the enterprise. Secondly, scientific research cooperation between universities and enterprises can be promoted so that innovation abilities of universities and R\&D abilities of enterprises can be integrated and finally universities can get better understanding of actual economic development status. Enterprises' innovation enthusiasm will surge ahead under the help of scientific research forces in universities so as to boost rapid and good development of photovoltaic industry. Thirdly, production cycle of photovoltaic enterprises is long, so fund withdrawal is slow, and then the government can delay tax payment like for 1-2 years to relieve pressure of photovoltaic enterprises in capital. Empirical analysis results indicate that supporting photovoltaic enterprises through fiscal taxation policies can not only solve problems encountered during enterprise development process like capital difficulty and compensate for deficiencies of market economy but also can facilitate enterprises to improve their own $R \& D$ innovation abilities so as to promote their growth.

\section{CONCLUSIONS}

In order to analyze influence mechanism of governmental subsidies on growth of photovoltaic enterprises, photovoltaic enterprises listed in Chinese A-share market during 2007-2017 were selected in this study as sample data. An empirical ana- 
Table 3. Regression Analysis

\begin{tabular}{|c|c|c|}
\hline $\begin{array}{l}\text { Explaining } \\
\text { Variable }\end{array}$ & Model (1) & Model (2) \\
\hline$F$ & $\begin{array}{c}0.056^{* *} \\
(1.754)\end{array}$ & \\
\hline$T$ & & $\begin{array}{l}0.003 * \\
(1.543)\end{array}$ \\
\hline Size & $\begin{array}{c}-1.085^{* * *} \\
(-11.056)\end{array}$ & $\begin{array}{r}-1.054 * * * \\
(-10.328)\end{array}$ \\
\hline$D E L$ & $\begin{array}{c}-0.016 \\
(-0.628)\end{array}$ & $\begin{array}{c}-0.014 \\
(-0.569)\end{array}$ \\
\hline Debt & $\begin{array}{c}-1.758^{* * *} \\
(-6.425)\end{array}$ & $\begin{array}{c}-1.853 * * * \\
(-7.056)\end{array}$ \\
\hline$R D I$ & $\begin{array}{c}3.530 * * \\
(2.021)\end{array}$ & $\begin{array}{c}3.352 * * \\
(1.898)\end{array}$ \\
\hline CON & $\begin{array}{c}0.365 \\
(1.126)\end{array}$ & $\begin{array}{c}0.306 \\
(0.896)\end{array}$ \\
\hline Constant & $\begin{array}{c}14.796^{* * *} \\
(12.756)\end{array}$ & $\begin{array}{c}14.253^{* * *} \\
(12.355)\end{array}$ \\
\hline Year & control & control \\
\hline Adjusted $\mathrm{R}^{2}$ & 0.452 & 0.456 \\
\hline F-test Value & $31.556^{* * *}$ & $31.895 * * *$ \\
\hline
\end{tabular}

Notes: * **, and $* * *$ represents significance at the $10 \%, 5 \%$, and $1 \%$ level, respectively, and the number in the brackets is T-test value.

lysis was carried out for effects of direct subsidies and tax preferences on growth of photovoltaic enterprises. The following research conclusions were drawn:

- Governmental fiscal subsidies have positive effect on growth of photovoltaic enterprises. As photovoltaic industry has high technical threshold, it needs input of a large quantity of capital cost. Especially for newly established enterprises, direct subsidy of governmental finance can effectively increase R\&D input in photovoltaic enterprises and reduce innovation risks of enterprises through allocation of financial resources.

- Governmental tax preferences have positive influence on growth of photovoltaic enterprises. The government can transfer partial revenue to enterprises, guide and motivate photovoltaic enterprises to carry out technological innovation activities and promote enterprise self-innovation so as to reduce enterprise cost and operation risk, improve enterprise revenue and finally boost enterprise development.
- Compared with tax preference, fiscal subsidy has more obvious effect on growth of photovoltaic enterprises. As it's difficult for photovoltaic enterprises to obtain capital support from traditional channel and they can't enjoy substantial preferential tax policies in financial aspect, lack of fund is always the primary problem faced by photovoltaic enterprises during development process and it restricts enterprise growth. Therefore, fiscal subsidy can not only solve fund-lacking problem of photovoltaic enterprises and compensate for deficiencies of market economy but also can facilitate enterprises to improve their own R\&D self-innovation abilities so as to boost growth of photovoltaic enterprises.

\section{REFERENCES:}

1. Ming, Z., Shaojie, O., Hui, S., et al. Is the "Sun" still hot in China? The study of the present situation, problems and trends of the photovoltaic industry in China. Renewable and Sustainable Energy Reviews, 2015. V43, pp.1224-1237. 
2. Ketels, C. H.M. Industrial Policy in the United States. Journal of Industry Competition \& Trade, 2007. V7, \#3, pp.147-167.

3. Donghua, Y., Yinan, L. Government Improper Intervention and Overcapacity of Strategic Emerging Industries: A Case Study of Chinese Photovoltaic Industry. China Industrial Economics, 2015. \#10, pp.53-68.

4. Bergström, F. Capital subsidies and the performance of firms. Small business economics, 2000. V14, \#3, pp.183-193.

5. Dongmin, K., Tianshang, L. Does government subsidy enhance corporate performance and social responsibility? Securities Market Herald, 2014. \#6, pp.26-31.

6. Cerqua, A., Pellegrini, G. Do subsidies to private capital boost firms' growth? A multiple regression discontinuity design approach. Journal of Public Economics, 2014. V109, pp.114-126.

7. Qingquan, T., Danglun, L. An empirical study on the motives and effects of government subsidy: empirical evidence from Chinese listed companies. Journal of Financial Research, 2007. \#6A, pp.149-163.

8. Wanfu, L., Jing, D. Tax Incentives, Adjustment Costs, and R\&D Investment in China. Accounting Research, 2016. \#12, pp.58-63.
9. Stulz, R.M. Tobin's Q, Corporate Diversification, and Firm Performance. Journal of Political Economy, 1994. V102, \#6, pp.1248-1280.

10. Xiaozhen, W., Jingya, Y., Yuzhu, W., et al. Review on the Influence of Government Subsidy on Firm's R\&D Input. R\&D Management, 2017. V29, \#1, pp.139-148.

11. Hatos, A. Clientele vs. Status Seeking? Subject Field Choice in Higher Education in the Hungarian-Romanian Cross-border Region. Revista de Cercetare si Interventie Sociala, 2017. V59, pp. 153-168.

12. Xuhong, L. A positive analysis of tax preference and SME growth ability. Taxation Research, 2014. \#8, pp.79-84.

13. Charles, B., Pierre, M. Are Firms that Receive R\&D Subsidies More Innovative? Canadian Journal of Economics, 2009. V42, \#1, pp.206-225.

14. Chuanxian, L., Xiaoyu, L. Government Subsidy, Market Development and Corporate Growth: A Literature Review. Journal of Southwest University of Political Science \& Law, 2016. \#3, pp.62-67.

15. Gopal, Y., Kumar, K., Birla, D., et al. Banes and Boons of Perturb \& Observe, Incremental Conductance and Modified Regula Falsi Methods for Sustainable PV Energy Generation. Journal of Power Technologies, 2017. V97, \#1, pp.35-43.

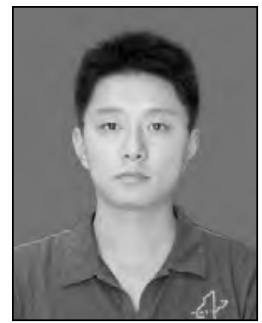

Ya'ou ZHANG,

Master of Finance, Lecturer. Graduated from the Kharkiv National V.N. Karazin University, Ukraine. The research direction is industrial economy 